Special Issue "Physical Limnology"

Guest Edited by Prof. Adam Choiński and Prof. Mariusz Ptak

Limnol. Rev. (2020) 20, 2: 51-58

DOI 10.2478/limre-2020-0006

\title{
Applicability of airborne laser scanning in the identification of lake shorelines
}

\author{
Mariusz Ptak, Adam Choiński*, Aleksandra Pych, Jan Piekarczyk \\ Institute of Physical Geography and Environmental Planning, Adam Mickiewicz University, \\ Krygowskiego 10, 61-680 Poznań, Poland, \\ e-mail: ptakm@amu.edu.pl (" ${ }^{*}$ corresponding author, M.P.); choinski@amu.edu.pl (A.C.); \\ alepyc@st.amu.edu.pl (A.P.); piekjan@amu.edu.pl (J.P.)
}

\begin{abstract}
The paper presents the applicability of LiDAR data in limnological research with respect to the identification of the shoreline of lakes, and consequently the scale of overgrowing of lakes. Data obtained from the Head Office of Geodesy and Cartography from the period 20112016 provided the basis for the identification of shorelines for 14 lakes of the Pomeranian Lakeland. The paper employs the orthophotomap for the determination of the range of lake vegetation. Using the line determined based on the orthophotomap and that determined based on LiDAR points, the zone of overgrowing of the analysed lakes was delineated. In all the analysed cases combined, the water surface area was found to be reduced in comparison to the shoreline identified through LiDAR scanning by 161.5 ha, suggesting a $21.2 \%$ share of vegetation in the surface area of lakes.
\end{abstract}

Key words: shoreline, laser scanning, overgrowing, LiDAR

\section{Introduction}

The shoreline is the boundary between the lake and land. According to Choiński (2007), it is the line of average water level, corresponding to the mean value of isobath $0 \mathrm{~m}$. The value of the indicator is expressed in metres or kilometres, and can concern the lake basin itself, islands, and total length, i.e. total length of the shoreline of the basin and islands. In environmental terms, the shoreline is the boundary between two ecosystems with a completely different way of functioning - water and land (Kulczyk et al. 2016). Despite a clear definition of lake shoreline, its precise outlining is not always an easy task. It is determined by situations where the lake is not subject to continuous water level measurements, or where the conditions on the interface of water and land do not permit proper identification of the boundary between them. This particularly occurs in the case of the occurrence of water or water-land vegetation, and is usually related to the evolution of lakes and vegetation succession in the littoral zone. Although the zone does not constitute open water, it is an integral part of water ecosystems, considerably affecting their functioning (migration of pollutants, biodiversity, effect on water transparency, etc.). In extreme cases, it can reach a width of several hundred metres, e.g. on the southern shore of Lake Łebsko. Moreover, precise determination of the range of a lake is particularly important in terms of the economy and settlement (Ptak 2012; Marszelewski and Marszelewski 2014; Nowak 2016).

The objective of the paper is to analyse the applicability of LiDAR data in research concerning the identification of the shoreline of lakes, as well as the possible application of the obtained data in the determination of the scale of overgrowing of lakes. The study was conducted on 14 lakes of the Pomeranian Lakeland (Fig. 1). The criterion for their selection was diverse shore vegetation and variable morphometric parameters. 


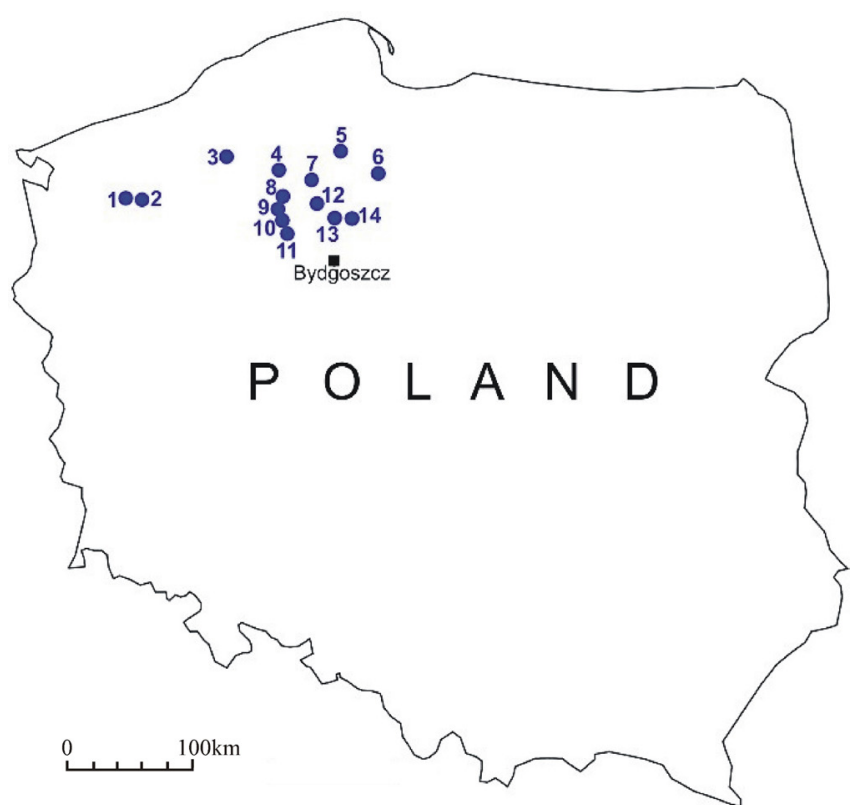

Fig. 1. Location of the analysed lakes: 1) Węgorzyno, 2) Żabice, 3) Smoleńsko, 4) Kłodzko Duże, 5) Wieckie, 6) Smarzewskie, 7) Grochowskie, 8) Lutowskie, 9) Koniczne, 10) Topola, 11) Witosławskie, 12) Minikowskie, 13) Rudno, 14) Piaseczno

\section{Materials and methods}

The adopted study objective was implemented through the identification of shorelines based on data obtained from airborne laser scanning and aerial photographs. The paper employs two data sets. The laser scanning data were obtained from the Head Office of Geodesy and Cartography (GUGiK). They were collected among others for the purposes of development of the Computer System of State Protection (ISOK). The principle of functioning of laser scanning involves the measurement of distances from points on the land surface to the flying plane. The laser mounted on board the plane sends a light beam in the form of impulses that then return to the detector. The time passing between sending the beam and its return is described as the distance of a point on the Earth's surface. The resulting point cloud is subject to classification. For the purposes of the study, data were obtained after point cloud classification.

The data used in the study were collected in the period 2011-2016. The measurement data were divided into blocks which were in turn divided into smaller sheets with a size of $1 \mathrm{~km}$. This study employed data from blocks with the following numbers: 1044, 1055, 1058, 1505, 2008, 2011, 2044 , 2045, 2047, 2510.
The orthophotomaps were prepared based on auxiliary data in the form of digital aerial photographs obtained from the Head Office of Geodesy and Cartography. Photographs for the analysed lakes are from the same period as the data from laser scanning.

For the purpose of identification of lake shorelines, two lines were determined on each of them. One of them was determined based on the orthophotomap and aerial photographs, and the other one based on the variable display of the point cloud.

The processing of LiDAR data and aerial photographs was done in the MicroStation PowerDraft programme by Bentley, and applications TerraScan, TerraModeler, and TerraPhoto by Terrasolid.

\section{Results and discussion}

Based on the example of Lake Rudno, differences in the course of the shoreline were presented, corresponding with its obscuring by tree crowns where in the southern part of the lake the shores are overgrown by trees with extensive crowns, which also frequently inclined towards the water. The shore was marked with a yellow line based on the orthophotomap, and a blue line based on LiDAR data (Fig. 2).

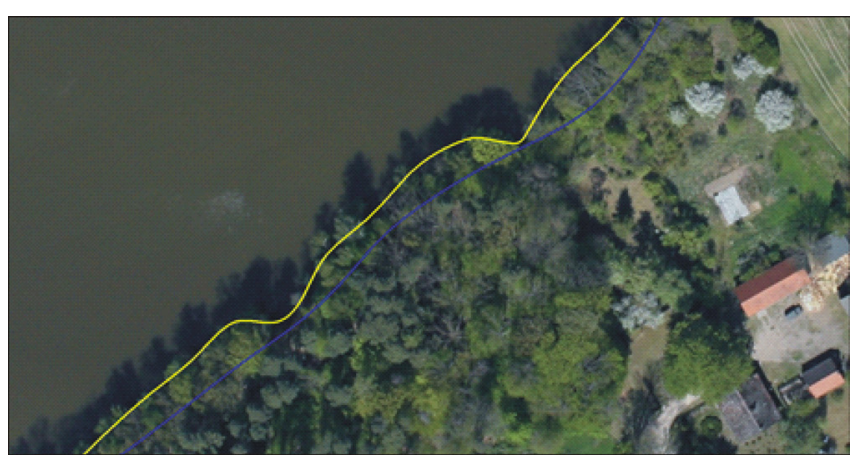

Fig. 2. Orthophotomap with a fragment of shore of Lake Rudno obscured by tree crowns. Data source: GUGiK

The difference between these data is evident. In the case of Lake Rudno, the difference between the determined lines reaches from $3 \mathrm{~m}$ to as much as $9 \mathrm{~m}$. Trees in the photographs not only obscure the shoreline with their crowns but also create shadows that additionally complicate the identification of the water range, as e.g. in the case of Lake Węgorzyno (Fig. 3).

A problem also stems from the fact that the 


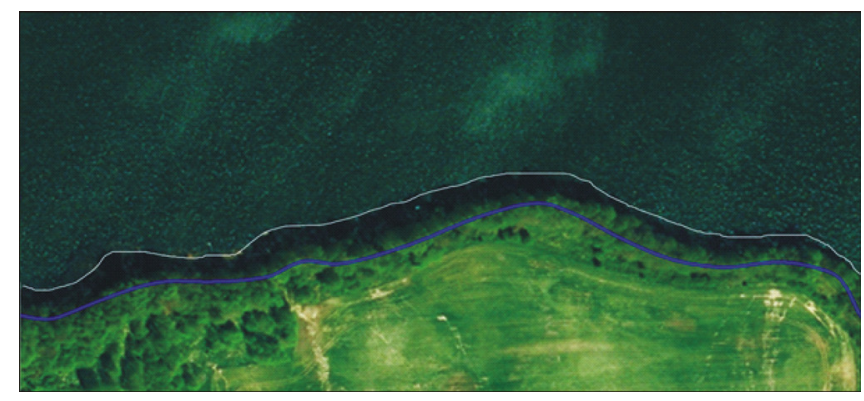

Fig. 3. Shading (white line) of the shore of Lake Węgorzyno by tree crowns. Data source: GUGiK

majority of the photographs were taken at a certain angle, making the trees look even more inclined and obscuring a greater share of the shore. The possibilities of laser scanning are evident in the cross-section through the point cloud in the place of the shore obscured by tree crowns. In the image displayed both by point height and by class, the place where land "rises" and water surface ends is evident. It was additionally marked in the crosssection with a blue line. The yellow line points to the place where the shore was determined based on the orthophotomap image (Fig. 4).

Another factor contributing to inaccurate identification of water range is rush vegetation and wetlands occurring around the analysed lakes. An interesting example are the shores of Lake Smarzewskie. The identified shorelines show considerable differences. Extensive littoral zones occur there. They are observed in the orthophotomap image, but with a range that is difficult to determine. Therefore, the water range delineated based on the photograph was determined in a place where the evident water surface ends and vegetation begins (Fig. 5).

During scanning of the area of Lake Smarzewskie, waving action occurred, reflecting the laser beam. Due to this, water surface points were obtained, additionally facilitating the determination of its range. Infrared laser beam (1064 nm) is very strongly absorbed by water, and does not return to the scanner, causing gaps in data. In the case of even slight waving, however, the beam is refracted and partially returns to the measurement device. In the cross-section through the place of occurrence of rush vegetation (Fig. 6), the land points marked in brown are exactly on the same level as the water points (marked as white), with rush vegetation such as reed and bushes above them. A place is also visible where the land is elevated (Fig. 7). It is worth
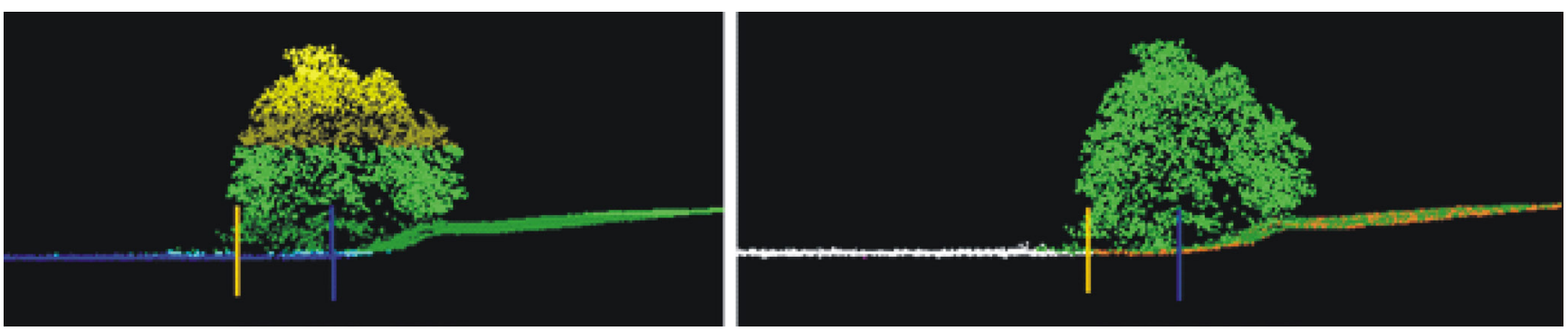

Fig. 4. Cross-section through the shore of Lake Węgorzyno overgrown by trees. The yellow line designates water range based on the orthophotomap, the blue line - water range based on laser scanning. To the left: points displayed by height, to the right: points displayed by class. Data source: GUGiK

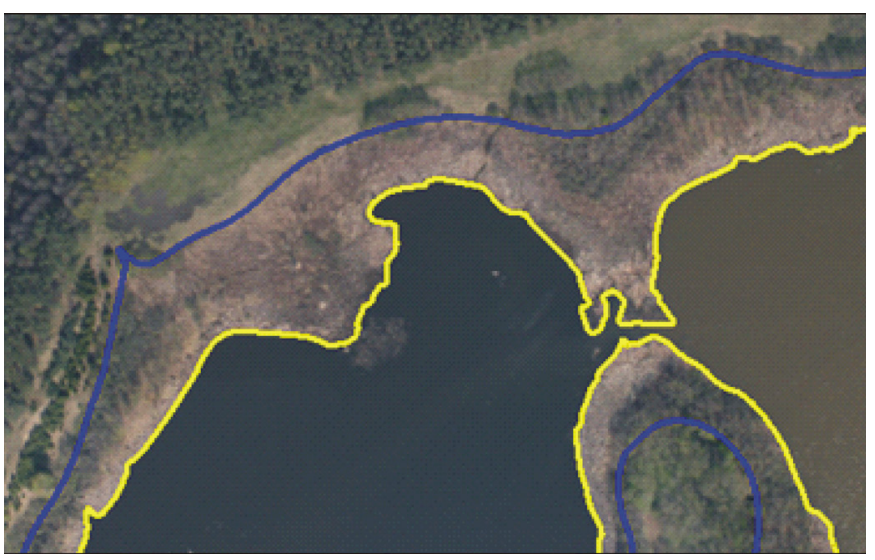

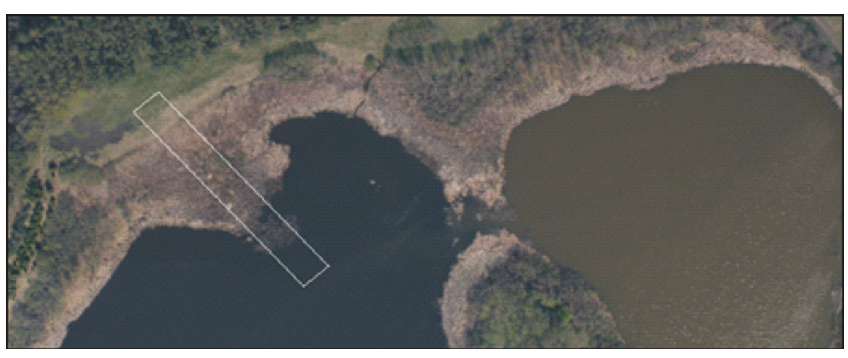

$\Delta$ Fig. 6. Fragment of Lake Smarzewskie with marked location of the cross-section. Data source: GUGiK

4 Fig. 5. Lines of water range on Lake Smarzewskie. Yellow line - range based on orthophotomap, blue line - range based on laser scanning. Data source: GUGiK 
emphasising that when shores are strongly overgrown, water points are conventionally not classified, and left in the land class. This was also the assumption in the classification in project ISOK. Thus, land points located at the same height as water points should be classified as water, although they were ascribed to another class. In reality, the water surface should end where land is elevated. Therefore, the blue line of the water range was drawn not where the water class ends, but in a place recognised as the actual range of the water surface.

Based on the example of Lake Smarzewskie, it is also worth drawing attention to areas overgrown by trees that do not obscure the shoreline with their crowns, but grow in the wetland area (Fig. 8). Similarly to rush vegetation, the determination of water range can also be attempted in this case. It is very difficult to unambiguously determine such a range based on an aerial photograph, however. The application of laser scanning in such analyses provides for much more extensive possibilities.

As in the case of rush vegetation, the crosssection shows (Fig. 9) that the area is flat and located on a level identical to that of the water surface. It may not be a flooded area, but it is highly likely to be a wetland.

The difference between the surface area based on laser scanning and the surface area obtained from the orthophotomap constitutes the area of the zone of overgrowing of the analysed lakes. A higher water surface area determined based on LiDAR data results from the possibilities of presentation of the image in a spatial form. The flat image of the aerial photograph does not permit the determination of

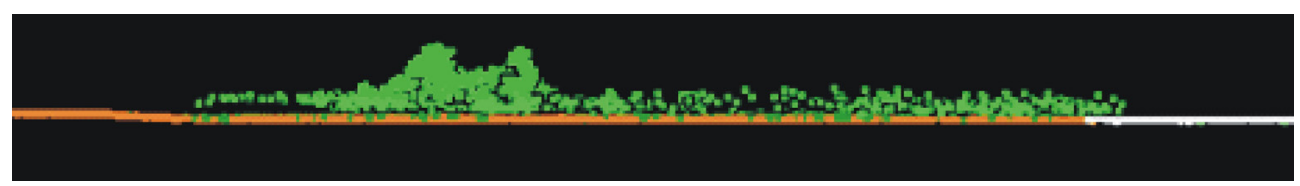

Fig. 7. Cross-section through the shore of Lake Smarzewskie overgrown with rush vegetation. White colour - water class, brown colour - land class, green colour - vegetation classes. Data source: GUGiK

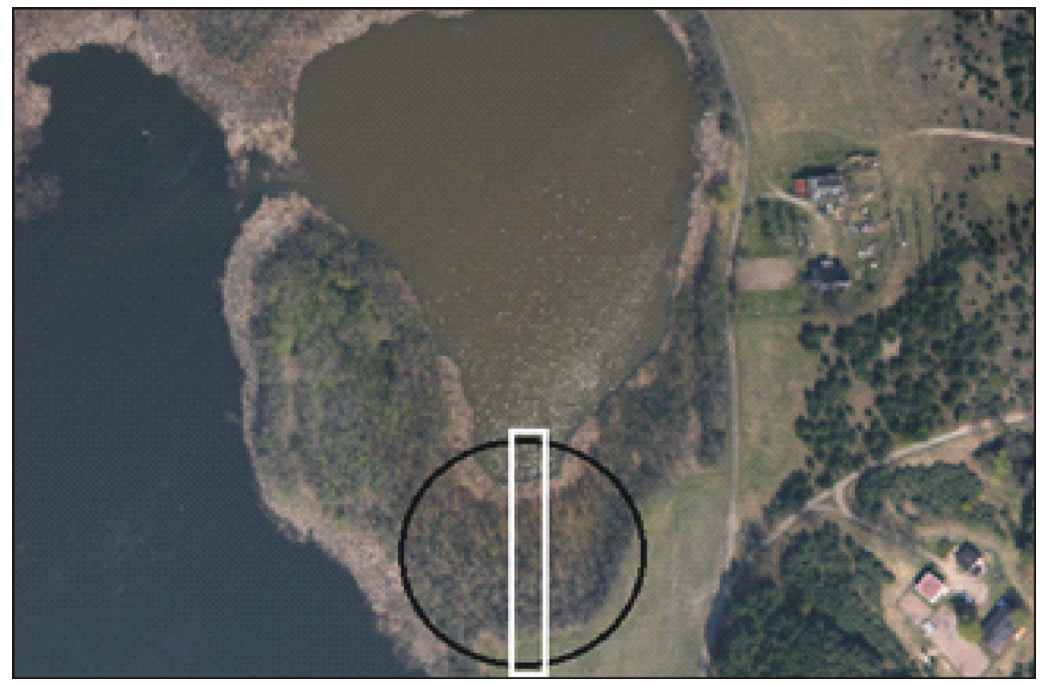

Fig. 8. Fragment of Lake Smarzewskie with an area overgrown by forest growing on wetlands marked in black, and the location of the cross-section marked in white. Data source: GUGiK

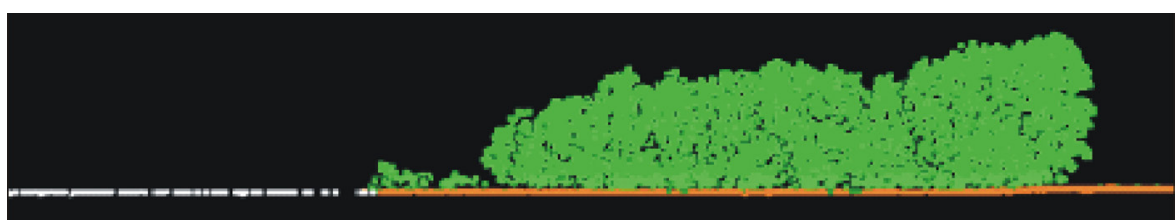

Fig. 9. Cross-section through the shore of Lake Smarzewskie with a forest growing on a wetland. Data source: GUGiK 
land elevation or height of vegetation. There is also no possibility of "looking" under tree crowns. Laser scanning allows for this kind of observation. Fig. 10 presents the range of overgrowing of lakes, and Table 1 presents differences in surface area obtained by means of both methods.
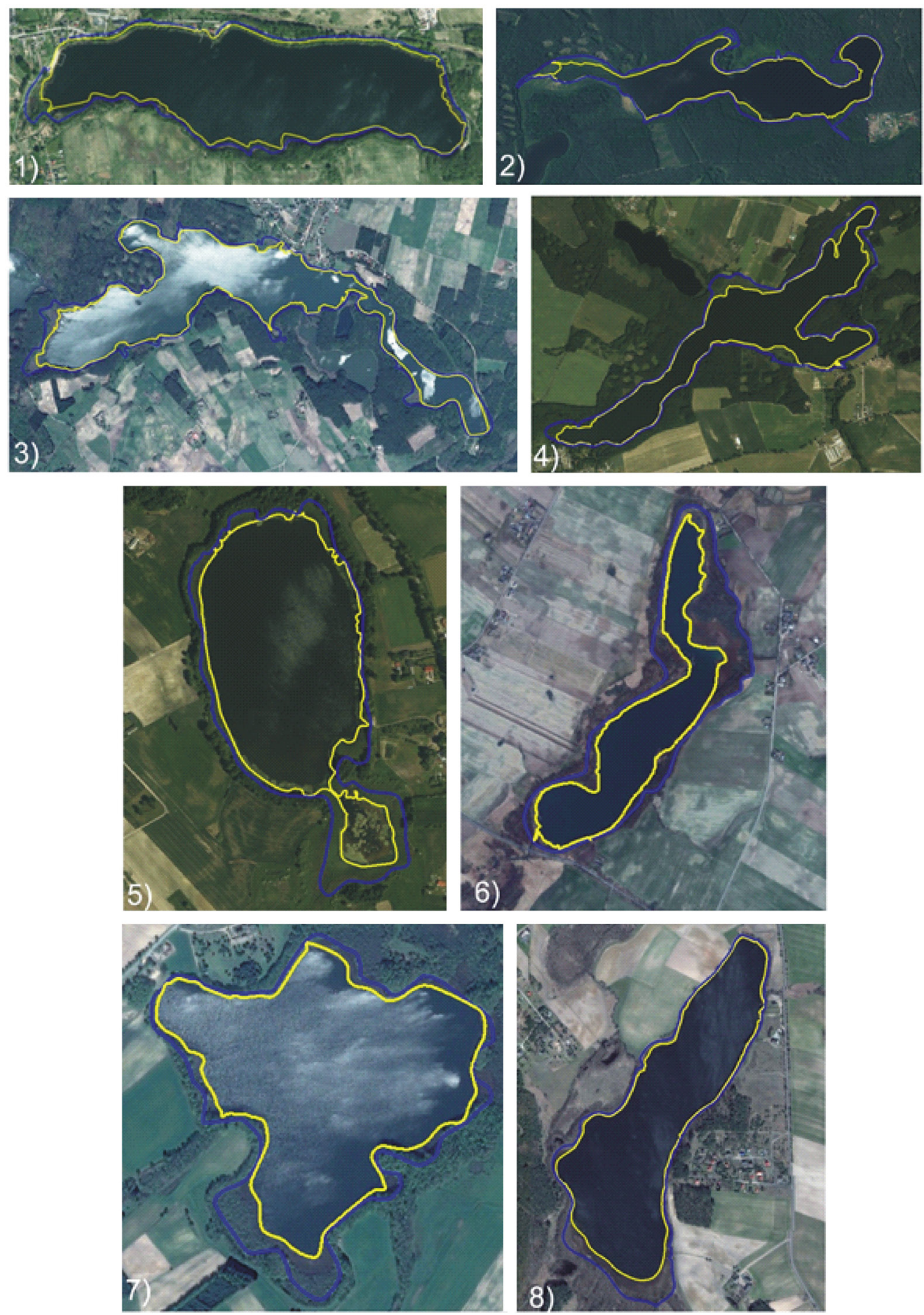

Fig. 10. Zones of overgrowing of lakes determined based on the orthophotomap and LiDAR data. Lakes: 1) Węgorzyno, 2) Smoleńsko, 3) Lutowskie, 4) Witosławskie, 5) Topola, 6) Grochowskie, 7) Koniczne, 8) Piaseczno, 9) Minikowskie, 10) Żabice, 11) Rudno, 12) Smarzewskie, 13) Wieckie, 14) Kłodzko Duże; yellow line - orthophotomap, blue line - LiDAR data. Data source: GUGiK 
The above data show that in all cases changes in the surface area of lakes were recorded as a result of vegetation succession. The total surface area of the analysed lakes decreased in comparison to the shoreline determined based on LiDAR by 161.5 ha. The figure shows the variability of the scale of overgrowing of particular lakes. The highest share (49.0\%) was recorded in the case of Lake Kłodzko Duże - the shallowest of all the analysed lakes (mean depth $0.9 \mathrm{~m}$ ).
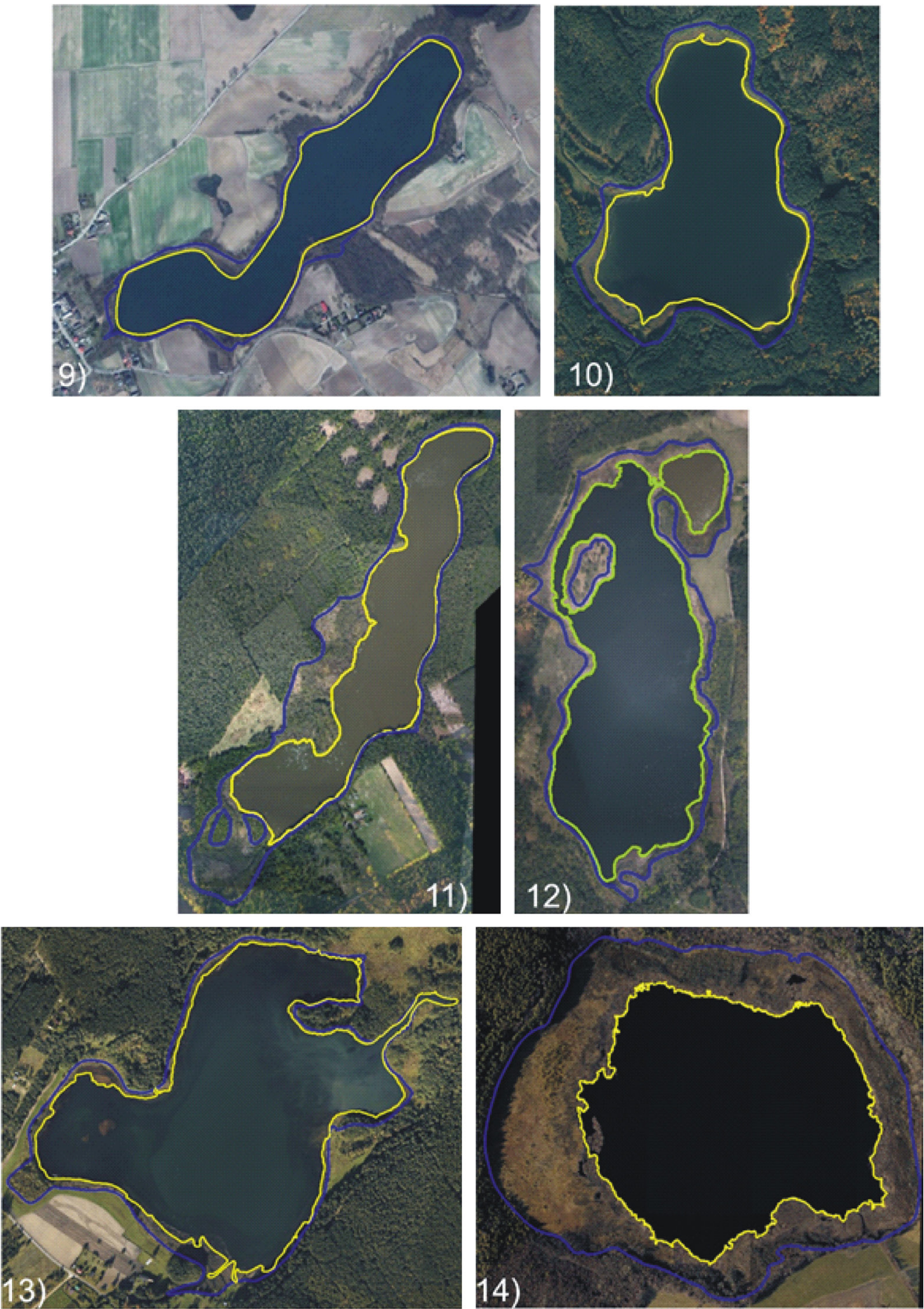

Fig. 10. Continuation 
Table 1. Surface area delineated by the shoreline determined by means of LiDAR, orthophotomap, and share of overgrowing of lakes

\begin{tabular}{|c|c|c|c|c|c|}
\hline \multirow{3}{*}{ Lake } & \multicolumn{2}{|c|}{ Surface area } & \multirow{2}{*}{$\begin{array}{l}\text { Surface area } \\
\text { difference }\end{array}$} & \multirow{2}{*}{$\begin{array}{l}\text { Share of lake } \\
\text { overgrowing }\end{array}$} & \multirow{2}{*}{$\begin{array}{l}\text { Mean } \\
\text { depth }\end{array}$} \\
\hline & Based on LiDAR & $\begin{array}{c}\text { Based } \\
\text { on orthophotomap }\end{array}$ & & & \\
\hline & [ha] & [ha] & [ha] & [\%] & [m] \\
\hline Węgorzyno & 66.0 & 59.5 & 6.5 & 9.8 & 4.2 \\
\hline Żabice & 565 & 45.5 & 11.0 & 19.5 & 1.9 \\
\hline Smoleńsko & 44.5 & 36 & 8.5 & 19.1 & 1.8 \\
\hline Kłodzko Duże & 50 & 25.5 & 24.5 & 49.0 & 0.9 \\
\hline Wieckie & 37 & 31.5 & 5.5 & 14.9 & 2.9 \\
\hline Smarzewskie & 48.5 & 37.5 & 11 & 22.7 & 2.2 \\
\hline Grochowskie & 58.5 & 34.5 & 24 & 41.0 & 2.2 \\
\hline Lutowskie & 122 & 103 & 19 & 15.6 & 3.8 \\
\hline Koniczne & 28 & 23 & 5 & 17.9 & 5.0 \\
\hline Topola & 21.5 & 17.5 & 4 & 18.6 & 4.4 \\
\hline Witosławskie & 141 & 117.5 & 23.5 & 16.7 & 7.0 \\
\hline Minikowskie & 25.5 & 22 & 3.5 & 13.7 & 2.6 \\
\hline Rudno & 32 & 21 & 11.0 & 34.4 & 2.6 \\
\hline Piaseczno & 31 & 26.5 & 4.5 & 14.5 & 8.4 \\
\hline Total & 762.0 & 600.5 & 161.5 & - & - \\
\hline
\end{tabular}

The obtained results correspond with an extensive research trend concerning changes in the surface area of lakes (Kowalewski 2011; Choiński and Ptak 2009; Ptak et al. 2013; Choiński et al. 2014, 2016). Studies concerning this issue include a group of papers focused on overgrowing of lakes (Ławniczak 2010; Ptak 2013; Choiński and Kijowski 2016; Skowron and Jaworski 2017; ŁawniczakMalińska et al. 2018).

\section{Conclusion}

The identification of the shoreline of lakes is not always an easy task. Modern possibilities and teledetection techniques, however, permit a new approach to the issue. One of such methods is laser scanning that can be used as an independent data source or combined with other spatial data allowing for a better interpretation of the point cloud and offering better perspectives of its use. Such an approach was employed in the paper in the identification of the shoreline. and then in combination with an orthophotomap in the determination of the scale of overgrowing of the analysed lakes. This technology will certainly be increasingly frequently applied in limnological research as well as in other geographic disciplines.

\section{References}

Choiński A., 2007, Limnologia fizyczna Polski (Physical limnology of Poland), Wydaw. Nauk. UAM, Poznań, 547 pp (in Polish).

Choiński A., Ptak M., 2009, Lake infill as the main factor leading to lake's disappearance, Pol. J. Environ. Stud. 18(3): 347-352.

Choiński A., Ptak M., Strzelczak A., 2014, Present-day evolution of coastal lakes based on the example of Jamno and Bukowo (the Southern Baltic coast), Oceanol. Hydrobiol. Stud. 43(2): 178-184.

Choiński A., Ławniczak A., Ptak M., 2016, Changes in water resources of Polish lakes as influenced by natural and anthropogenic factors, Pol. J. Environ. Stud. 25(5): 1883-1890.

Choiński A., Kijowski A., 2017, Fotolimnologia (Photolimnology), Wydaw. Nauk. UAM, Poznań, 134 pp (in Polish).

Kowalewski G., 2011, Shoreline and surface area changes induced by floating islands in peatland lakes (Tuchola Pinewood Forest, Poland), Limnol. Rev. 4: 151-162. 
Kulczyk S., Derek M., Woźniak E., 2016, Zagospodarowanie turystyczne strefy brzegowej jezior na potrzeby żeglarstwa - przykład wielkich jezior mazurskich (Shore facilities for sailing - the example of Great Masurian Lakes), Pr. Stud. Geogr. 61(3): 27-49 (in Polish, English summary).

Ławniczak A., 2010, Overgrowing of two polymictic lakes in Central-Western Poland, Limnol. Rev. 10(34): 147-156.

Ławniczak-Malińska A., Ptak M., Celewicz S., Choiński A., 2018, Impact of lake morphology and shallowing on the rate of overgrowth in hard-water eutrophic lakes, Water 10(12): 1827.

Marszelewski M., Marszelewski W., 2014, Prawo powszechnego dostępu do wód publicznych i problemy z jego wykonywaniem ze szczególnym uwzględnieniem jezior (The right of common access to public waters and problems with its exercise with particular emphasis on lakes), Prz. Pr. Ochr. Środ. (PPOŚ) 4: 131-159 (in Polish).

Nowak B., 2016, Wyznaczanie linii brzegowej jezior w Polsce - zapisy w ustawie a uwarunkowania przyrod- nicze i gospodarcze (Determining shoreline of lakes in Poland - provisions of the legal act versus natural and economic considerations), Gosp. Wod. 10: 345350 (in Polish, English summary).

Ptak M., 2012, Jeziora Pojezierza Wielkopolsko-Kujawskiego jako baza rekreacyjno-wypoczynkowa (Lakes of the Greater Poland-Kuyavian Lakeland as a recreation and leisure base), Bad. Fizjogr. A 63: 111-120 (in Polish).

Ptak M., 2013, Historical medium-scale maps as a source of information on the overgrowing of lakes, Limnol. Rev. 13(3): 155-162.

Ptak M., Choiński A., Strzelczak A., Targosz A., 2013, Disappearance of Lake Jelenino since the end of the XVIII century as an effect of anthropogenic transformations of the natural environment, Pol. J. Environ. Stud. 22(1): 191-196.

Skowron R., Jaworski T., 2017, Changes in lake area as a consequence of plant overgrowth in the South Baltic Lakelands (Northern Poland), Bull. Geogr. Phys. Geogr. 12: 19-30. 